\title{
PRIMARY HEALTH CARE AND ALCOHOL
}

\author{
Kaija Seppa ${ }^{1}$
}

\begin{abstract}
In his famous novel 'Anna Karenina' Konstantin Levin, a farmer who is commonly considered to represent the author Leo Tolstoy himself, listens to another farmer's opinions on the land reform. He highly respects these opinions which, as he says, 'had been brought not by a desire of finding some exercise for an idle brain, but a thought which had grown up out of the conditions of his life'.

Researchers and policy makers, far from the realities of primary health care, seem to be more interested in brief alcohol interventions for hazardous drinkers than do general practitioners or other professionals working in this setting. Should brief intervention be removed to some other setting, buried forever as not being suitable for real life, or would it just now be perfect time for general practitioners and nurses in primary health care to take command of brief interventions and make it suitable for their own setting?
\end{abstract}

Key words: brief intervention, general practitioner, implementation, nurse, screening, hazardous and harmful alcohol drinking

\section{Primary health care and alcohol}

General practitioners (GPs) need a huge spectrum of skills to look after their patients' health. Their knowledge has to cover the updated diagnostic and treatment trends of a wide variety of diseases, but also the preventive actions against the increasing risks of living in the modern society. GP's surgery has been considered crucial in fighting against these risks, e. g. obesity, high blood pressure, cholesterol, smoking and excessive alcohol use.

\section{Prevention of addictive disorders in primary health care}

It has been easier for GPs to intervene in other than addictive risks. High blood pressure and high cholesterol preventions were relatively easily implemented in medical care. This may be because there are medicines to tackle these risks. Prescribing medicines is considered easier in the busy daily practice than discussing and motivating, the main methods against risky drinking. Brief alcohol intervention (BI) focuses on changing the hazardous and harmful, not yet addicted, risky behaviour towards low risk drinking. It includes asking about alcohol use and giving encouraging oral and written personal feedback in an empathetic atmosphere. $\mathrm{Bl}$ is not a fixed, homogeneous practice, but rather a family of interventions, which has different time-frames, content and targets and which can be delivered by a wide variety of providers (1). The number needed to treat (NNT) for BI is smaller than that for smoking. Only 8-10 hazardous drinkers need to be given an advice (2-4) compared to 50 smokers (5-9) to make the change. However, GPs talk quite often about smoking with their patients but, in spite of clear scientific evidence of the effectiveness of brief alcohol interventions in health care, its adoption by professionals has been slow $(10,11)$. The difference also may be that there are medicines for smoking but not for hazardous drinking. Attitudes may also play a role; smoking only endangers the patient's physical health, alcohol usually changes patient's mental health and often makes suffer patient's family and also outside society. Even professionals often consider alcohol addicted patients more guilty than ill. When asked why GPs do not ask and advise their patients about alcohol, a common explanation has been that they need more therapeutic, especially motivational skills. Thus, the obstacles to do $\mathrm{BI}$ can be found in negative attitudes, lack of skills but also in the daily routines of primary health care work $(10,12-19)$. Factors such as government support, management efforts, incentives and workplace programs are said to be needed to help the implementation of $\mathrm{BI}(1,20-22)$.

\section{Patients' opinions about alcohol discussions}

Some physicians are afraid of losing their patients if they raise the topic of alcohol. A post-consultation survey 
from Finland revealed that of those who had been asked about alcohol (235/665), 1.8\% had negative, $29.1 \%$ neutral, $20.2 \%$ positive and $48.8 \%$ very positive attitudes towards these questions (23). In a national survey over $90 \%$ of Finns aged 15-69 who had been in contact with health care during the past 12 months had positive attitudes towards being asked about their alcohol use (24).

Based on videotaped consultations and patient documents questions on alcohol do not necessarily lead to advice even when it would be appropriate $(25,26)$. This result is similar to surveys, where the information comes from patients $(27,28)$. On the other hand over two thirds of those who have been advised have considered it useful (24).

\section{Implementation results}

For years, there have been worldwide efforts to implement $\mathrm{BI}$ in primary health care $\mathrm{PHC})(1,22,29)$. In the USA BI for patients with hazardous and harmful alcohol use is a prevention priority, but most eligible patients do not receive it and there has been a call for more active implementation efforts (30). Even if the results of implementation are modest and the activity is still low, it can be concluded that the more intensive the implementation effort the better the result (11).

Two population-based studies from the USA have examined the rates at which alcohol and drug-use problems have been addressed in health care contacts during the previous 12 months. Data from 7301 primary care patients have revealed that alcohol or drug screening was given to $28.3 \%$ of patients; of those screened positive $43.3 \%$ received at least a suggestion to cut down on alcohol/drugs (27). In the 1998 Healthcare for Communities survey the corresponding figures were $29 \%$ and $48.6 \%$, respectively. Men, young people, those with higher education, with a higher number of medical conditions, a higher Alcohol Disorders Identification Test (AUDIT) score or living in urban areas were most often asked about their alcohol and drug use (28). In the Finnish populationbased survey about one third had been asked about their alcohol use, being most often men, young, heavy drinkers and those of high socioeconomic status. One third of those who had been asked were given advice, being most often heavy drinkers and those with a normal body mass index (24).

Other surveys have studied the same questions using data based on actual health care visits. In a Finnish exit-poll survey for patients ( $n=1203), 11.6 \%$ had been asked and/or advised on their alcohol consumption during the consultation in question (23). Lock and Kaner found that in England, $62 \%$ of risky drinkers were given advice by practice nurses. The AUDIT score was the most influential predictor of $\mathrm{BI}$, followed by male sex; the age of the patient, social class or characteristics of the nurses had no influence on the activity (21).

In the USA a national performance measure linked to incentives and dissemination of an electronic clinical reminder have increased the documented BI activity from $5.5 \%$ to $29 \%$ among Veterans Affairs outpatients with alcohol misuse (31). To find out the present nationwide $\mathrm{BI}$ activity as part of routine daily work, a questionnaire was mailed to all Finnish GPs working in public PHC. Of them $50.9 \%(1610 / 3163)$ answered and $78.5 \%$ of them reported to do Bl. Regular activity was reported by $17.2 \%$ and occasional activity by $61.3 \%$ (32). All the above studies indicate that the BI activity is opportunistic, not systematic.

\section{Professionals' opinion on alcohol discussions}

There are two different views of the practicability of $\mathrm{BI}$ in the PHC setting. One is that $\mathrm{BI}$ should be widely implemented. This conclusion is based on the fact of efficacy in several studies. The other opinion is that $\mathrm{BI}$, even if efficient, is not suitable for the PHC everyday work. Especially GPs have expressed this opinion. This can also be seen in that in spite of the manifold implementation efforts $\mathrm{BI}$ has not been widely implemented in primary or specialized health care. It has been calculated that about 300 patients should be screened to gain one improvement which means waste of GPs' time and money (33). On the other hand there are studies which show that $\mathrm{BI}$ is cost-effective and saves 4.3 times the money invested in it (34).

The problem with the scientific efficacy studies is that they have mainly not been part of health care's routine work and the activity is soon forgotten after the project ends. Especially the extra work to keep scientific diaries in the middle of the busy schedule has raised resistance against this work among general practitioners. They have even been considered useless for this activity and much emphasis has been put on involving nurses and other professionals in doing $\mathrm{BI}(1,21)$.

The leaders' opinions seem to have changed so that according to them $\mathrm{BI}$ should widely be done in $\mathrm{PHC}$ settings. Discussions on whether screening should be systematic or maybe some other way of action taken over are still going on. The leader driven activity to 
offer $\mathrm{BI}$ education for GPs has not been very popular and many GPs have even felt blamed of not doing BI.

\section{What could be feasible?}

There are strong scientific arguments in favor of doing $\mathrm{BI}$ in PHC, as well by GPs as by nurses. Also, the patients' positive opinion can be considered as a vote to continue developing this line of work. Some misunderstandings of $\mathrm{BI}$ still make many $\mathrm{PHC}$ professionals think that $\mathrm{BI}$ does not fit in the routine daily work. These misunderstandings are collected in Table 1.

Table1. Brief alcohol intervention in primary health care.

\begin{tabular}{ll} 
Prejudice & Reality \\
\hline $\begin{array}{l}\text { Therapeutic skills are } \\
\text { needed }\end{array}$ & $\begin{array}{l}\text { Basic communication } \\
\text { skills are sufficient } \\
\text { Difficult }\end{array}$ \\
$\begin{array}{l}\text { Extra time needed } \\
\text { Can be done as part of } \\
\text { normal work }\end{array}$ \\
$\begin{array}{ll}\text { Extra paperwork needed } \\
\text { Separate questionnaires }\end{array}$ & $\begin{array}{l}\text { Short verbal questions } \\
\text { possible } \\
\text { needed }\end{array}$ \\
Insults patients & $\begin{array}{l}\text { Helps patients } \\
\text { Comparable to other } \\
\text { Morally loaded }\end{array}$ \\
& discussions \\
\hline
\end{tabular}

The main obstacle and misunderstanding is that $\mathrm{BI}$ is something extra, something difficult. This opinion is maintained by researchers. It is naturally ambitious and important to improve the method (35). However, for basic needs in PHC simply 'shortly raising the topic' can lead to good results. The need for special techniques might frighten $\mathrm{PHC}$ staff and postpone the implementation - or even make it impossible due to the time needed for these discussions.

Another obstacle is the demand to use structured questionnaires. GPs rather use face-to-face interviews, not paper and pen questionnaires. Discussions about alcohol can be started with a simple open question, for example: 'Please, tell me about your alcohol consumption'. A good option could be a short structured questionnaire which could be used verbally. AUDIT-C could be an answer (36). The basic methods of preventive work require an inquiry into the individual's present situation and information needs, a relationship that tends towards a partnership rather than a didactic approach, constituting a verbal and personal contact.
One argument against $\mathrm{BI}$ is that GPs do not have therapeutic skills in case that a real problem is discovered. For hazardous drinkers written patient instructions are widely available in many countries. A hand-out and a couple of empathetic words serve as minimal brief intervention. If the patient is alcohol addicted there is always the possibility for referral to addiction specialists. Today, there is often a nearby professional who has learned more motivational skills. In any case, leaving the possible problem unnoticed is always a worse and a more unethical option than raising the topic - however thin one's own motivational skills are.

To have the science-based public health benefit of $\mathrm{BI}, 100 \%$ of the patients should be asked about their alcohol consumption during their lifetime. Opportunistic screening followed by BI (opportunistic SBI), e.g. starting with probable cases, for example trauma patients, can be an easy way to start the activity at institutional level and to gain some expertise and success experiences. Even in the long run opportunistic SBI only reaches a small proportion of cases and thus the public health benefit of SBI may be lost. A feasible path in PHC may be not to screen every patient at every appointment, but rather to use the continuum of care in order to gain basic information on the whole clientele and their lifestyles. Ideally, alcohol consumption should be inquired from at least all new patients when it feels convenient, hazardous and harmful drinking patients at every appointment, low risk drinking patients who represent with symptoms referring to hazardous drinking or have a long interval since the previous inquiry. Using this strategy, by time the GPs would have an updated record of every patient's alcohol use. This can be considered as a systematic screening tailored to the everyday work in PHC. Here, the optimal momentum and good patientdoctor relationship can be used to initiate SBI, without causing extra effort or economic losses in organizing a separate systematic survey.

To gain all this, specialist education in general practice/ family medicine/occupational health care is useful (37). Embedding wider preventive skills in these specialist programmes clearly serves in building the specialist identity. On the contrary, separate alcohol BI education sessions do not necessarily help in changing attitudes among those who are insecure and uncommitted and are only helpful for those who have good professional identity (38). Moreover, information of the fact that $\mathrm{BI}$ may enhance the quality of primary care (39) might promote the activity.

PHC professionals, GPs and nurses, are highly competent to do brief alcohol interventions. Just facing 
the challenge, forgetting moral loadings and using the existing expertise are needed. $\mathrm{BI}$ is not a long therapy, no time is lost, many patients will be pleased and their health will improve. Some colleague nearby could be interested in having further education in motivational skills and take responsibility of those patients who need more than the minimal intervention.

The ingredients for $\mathrm{BI}$ are available. As Tolstoy wrote, the decision whether to do or not to do should start from the main actors. Here it means GPs and nurses in PHC. Take the leadership, make a wise decision and tailor $\mathrm{BI}$ to your own and your patients' needs.

\section{References}

1. Heather N (Ed.). WHO Collaborative Project on Identification and Management of Alcohol-Related Problems in Primary Health Care: report on phase IV: development of countrywide strategies for implementing early identification and brief intervention in primary health care. Geneva: World Health Organization, 2006.

2. Salaspuro M. Intervention against hazardous alcohol consumption - secondary prevention of alcohol problems. In: Berglund $\mathrm{M}$, Thelander E, Jonsson E (Ed.) Treating alcohol and drug abuse. Weinheim: Wiley-VCH, 2003: 1-41.

3. Ballesteros J, Duffy JC, Querejeta I, Arino J, Gonzalez-Pinto A. Efficacy of brief interventions for hazardous drinkers in primary care: systematic review and meta-analyses. Alcohol Clin Exp Res 2004; 28: 608-18.

4. Kaner EFS, Beyer F, Dickinson HO, Pienaar E, Campbell F, Schlesinger C, Heather N, Saunders J, Burnand B. Effectiveness of brief alcohol interventions in primary care populations. Cochrane Database of Systematic Reviews 2007; 2: CDC004148.

5. West R, McNeill A, Raw M. Smoking cessation guidelines for health professionals: an update. Thorax 2000; 55: 987-99.

6. Silagy C, Stead LF. Physician advice for smoking cessation. Cochrane Database Syst Rev 2004; 4: CD000165.

7. Russell MA, Wilson C, Taylor C, Baker CD. Effect of general practitioners‘ advice against smoking. BMJ 1979; 2: 231-5.

8. Kreuter MW, Cheda SG, Bull FC. How does physician advice influence patient behaviour?: evidence for a priming effect. Arch Fam Med 2000; 9: 426-33.

9. West R, McEwen A, Bolling K, Owen L. Smoking cessation and smoking patterns in the general population: a 1-year follow-up. Addiction 2001; 96: 891-902.

10. Roche AM, Freeman T. Brief interventions: good in theory but weak in practice. Drug Alcohol Rev 2004; 23: 11-8.

11. Nilsen $P$, Aalto M, Bendtsen B, Seppä K. Effectiveness of strategies to implement brief alcohol intervention in primary health care - a systematic review. Scand J Primary Health Care 2006; 24: 5-15.

12. Aalto M, Pekuri $P$, Seppä K. Primary health care nurses' and physicians' attitudes, knowledge and beliefs regarding brief intervention for heavy drinkers. Addiction 2001; 96: 305-11.

13. Kääriäinen J, Sillanaukee $P$, Poutanen $P$, Seppä K. Opinions on alcohol-related issues among professionals in primary, occupational, and specialized health care. Alcohol Alcoholism 2001; 36: 141-6.

14. Johansson K, Bendtsen P, Åkerlind I. Early intervention for problem drinkers: readiness to participate among general practitioners and nurses in Swedish primary health care. Alcohol Alcoholism 2002; 37: 38-42.

15. Aira M, Kauhanen J, Larivaara P, Rautio P. Factors influencing inquiry about patients' alcohol consumption by primary health care physicians: qualitative semi-structured interview study. Family Practice 2003; 20: 270-5.

16. McCormic KA, Cochran NE, Back AL, Merrill JO, Williams EC Bradley KA. How primary care providers talk to patients about alcohol: a qualitative study. J Gen Intern Med 2006; 21: 966-72.

17. Saitz R, Friedmann PD, Sullivan LM, Winter MR, LloydTravaglini C, Moskowitz MA, Samet JH. Professional satisfaction experienced when caring for substance-abusing patients: faculty and resident physician perspectives. J Gen Intern Med 2002; 17: 373-7.

18. Kaner EFS, Heather N, McAvoy BR, Lock CA, Gilvarry E. Intervention for excessive alcohol consumption in primary health care: attitudes and practices of English general practitioners. Alcohol Alcohol 1999; 34: 559-66.

19. Poplas-Susič $T$, Kersnik J, Kolšek M. Why do general practitioners not screen and intervene regarding alcohol consumption in Slovenia?: a focus group study. Wien Klin Wochenschr 2010; 122 (Suppl 2): 68-73.

20. Kersnik J, Poplas-Susič T, Kolšek M, Švab I. What may stimulate general practitioners to undertake screening and brief intervention for excess alcohol consumption in Slovenia?: a focus group study. J Int Med Res 2009; 37: 1561-9.

21. Lock CA, Kaner EF. Implementation of brief alcohol interventions by nurses in primary care: do non-clinical factors influence practice? Family Practice 2004; 21: 270-5.

22. Babor TF, Higgins-Biddle JB. Alcohol screening and brief intervention: dissemination strategies for medical practice and public health. Addiction 2000; 95: 677-86.

23. Aalto M, Seppä K. Usefulness, length and content of alcoholrelated discussions in primary health care: the exit-poll survey. Alcohol Alcoholism 2004; 39: 532-5.

24. Mäkelä $P$, Havio M, Seppä K. Alcohol-related discussions in health care: a population view. Addiction [epub ahead of print]

25. Seppä K, Aalto M, Raevaara L, Peräkylä A. Brief intervention for risky drinking -analysis of videotaped consultations in primary health care. Drug Alcohol Review 2004; 23: 167-70.

26. Bradley KA, Williams EC, Achtmeyer CE, Volpp B, Collins BJ, Kivlahan DR. Implementation of evidence-based alcohol screening in the Veterans Health Administration. Am J Manag Care 2006; 12: 597-606.

27. Edlund MJ, Unützer J, Wells KB. Clinician screening and treatment of alcohol, drug, and mental problems in primary care. Medical Care 2004; 42: 1158-66.

28. D'Amico EJ, Paddock SM, Burnam A, Kung F-Y. Identification of and guidance for problem drinking by general medical providers. Medical Care 2005; 43: 229-36.

29. Seale JP, Monteiro MG. The dissemination of screening and brief intervention for alcohol problems in developing countries: lessons from Brazil and South Africa. Nordic Studies on Alcohol and Drugs 2009; 25: 565-77.

30. Williams EC, Achtmeyer CE, Kivlahan DR, Greenberg D, Merrill JO, Wickitzer TM et al. Evaluation of an electrionic clinical reminder to facilitate brief alcohol-counseling interventions in primary care. J Stud Alcohol Drugs 2010; 71: 720-5.

31. Lapham GT, Achtmeyer CE, Williams ED, Hawkins EJ, Kivlahan DR, Bradley KA. Increased documented brief alcohol interventions with a performance measure and electronic decision support. Med Care [epub ahead of print].

32. Seppä K, Kuokkanen M. Implementing brief alcohol intervention in primary and occupational health care: reflections on two Finnish projects. Nordic Studies on Alcohol and Drugs 2009; 25: 505-14. 
33. Beich A, Thorsen T, Rollnick S. Screening and brief intervention trials targeting excessive drinkers in general practice: systematic review and meta-analysis. Br Med J 2003; 327: 536-42.

34. Fleming MF, Mundt MP, French MT, Manwell LB, Stauffacher EA, Barry KL. Brief physician advice for problem drinkers: longterm efficacy and benefit-cost analysis. Alcohol Clin Exp Res 2002; 26: 36-43.

35. Heather $\mathrm{N}$. The case for extended brief interventions. Zdrav Var 2011; 50: 1-6.

36. Kriston L, Hölzel L, Weiser AK, Berner MM, Härter M. Metaanalysis: are 3 questions enough to detect unhealthy alcohol use? Ann Intern Med 2008; 149: 879-88.
37. Seppänen K, Aalto M, Seppä K. Influence of national brief intervention projects on brief intervention activity of Finnish primary care physicians. $7^{\text {th }}$ Conference of Inebria. Accessed March 21, 2011 from: www.inebria.net.

38. Anderson, P, Laurant, M, Kaner, E, Wensing, M, Grol, R. Engaging general practitioners in the management of hazardous and harmful alcohol consumption: results of a meta-analysis. J Stud Alcohol 2004; 65: 191-9.

39. Saitz R, Horton NJ, Cheng DM, Samet JH. Alcohol counseling reflects higher quality of primary care. J Gen Intern Med 2008; 23: $1482-6$. 


\title{
PRIMARNO ZDRAVSTVENO VARSTVO IN ALKOHOL Kaija Seppa ${ }^{1}$
}

\author{
Prispelo: 1. 4. 2010 - Sprejeto: 29. 6. 2010
}

\section{Povzetek}

Gostujoči uvodnik

V slavnem romanu „Ana Karenina«, Levin, kmet, za katerega velja, da predstavlja avtorja, Leva Tolstoja, posluša mnenje drugega kmeta o kmetijski reformi. Njegovo mnenje zelo spoštuje in meni, da » ne gre le za željo, da bi razgibal brezdelni um, temveč za misli, ki so zrasle iz razmer, v katerih živi. «

Zdi se, da so raziskovalci in politiki, oddaljeni od realnosti osnovnega zdravstvenega varstva, bolj naklonjeni kratkim ukrepom pri tveganih pivcih, kot to velja za zdravnike družinske medicine in druge strokovnjake s tega področja. Ali naj kratke ukrepe odrinemo drugam, jih za vse večne čase pokopljemo kot ukrepe, ki ne ustrezajo stvarnemu življenju, ali pa je prav zdaj pravi čas, da zdravniki družinske medicine in medicinske sestre v osnovnem zdravstvenem varstvu sprejmejo kratke ukrepe in jih prilagodijo svojemu delovnemu okolju?

Pri delu z bolniki potrebujejo zdravniki družinske medicine široko paleto znanj. Poznati morajo najsodobnejše smernice diagnosticiranja in zdravljenja najrazličnejših bolezni, pa tudi preventivne ukrepe zaradi vedno večjih tveganj, ki jih prinaša življenje $v$ sodobni družbi. Ambulanta zdravnika družinske medicine igra bistveno vlogo v boju proti dejavnikom tveganja, kot so debelost, visok krvni tlak, povišan holesterol, kajenje in prekomerno pitje alkohola.

Ključne besede: kratek ukrep, zdravnik družinske medicine, izvajanje, medicinska sestra, presejanje, tvegano in škodljivo pitje alkohola

\section{Preprečevanje bolezni zasvojenosti na primarni ravni}

Zdravniki na primarni ravni lažje ukrepajo pri tveganjih, ki niso povezana z uživanjem alkohola. Preprečevanje visokega krvnega tlaka in holesterola se je v zdravstvu sorazmerno hitro uveljavilo, morda zato, ker so za te dejavnike tveganja na voljo zdravila. Prezaposleni zdravniki raje predpišejo zdravilo, kot pa si vzamejo čas za motivacijski pogovor, ki je najpomembnejša metoda pomoči pri prekomernem pitju alkohola. Bistvo kratkih ukrepov je preusmerjanje tveganega in škodljivega vedenja posameznika, ki še ni zasvojen, k manj tveganemu pitju. Zdravnik pacienta povpraša o pivskih navadah, in mu nato s sočutjem in empatijo ponudi spodbudne pisne in ustne povratne informacije. Kratki ukrepi niso trdno določeni in homogeni, gre bolj za skupino ukrepov z različnimi časovnimi okviri, vsebino in cilji, ki jih lahko izvajajo različni zdravstveni delavci (1). Število tistih, pri katerih je treba izvesti kratke ukrepe zaradi pitja alkohola, da eden od njih zmanjša pitje (»number needed to treat - NNT «), je manjše, kot je pri kadilcih. V primerjavi s 50 kadilci (5-9), je le pri 8 do 10 tveganih pivcih (2-4) potrebno dati nasvet, da se eden odloči za zmanjšanje pitja. Zdravniki družinske medicine se s svojimi bolniki pogosto pogovarjajo o kajenju, kratki ukrepi zaradi prekomernega pitja alkohola pa se kljub trdnim znanstvenim dokazom o njihovi učinkovitosti, le počasi uveljavljajo $(10,11)$. Gre verjetno tudi za to, da so za opustitev kajenja na voljo zdravila, za prenehanje tveganega ali škodljivega pitja pa ne. Pomemben je tudi odnos do tveganega vedenja: kajenje ogroža le telesno zdravje posameznika, alkohol pa navadno vpliva na pacientovo duševno zdravje in pogosto boleče poseže v življenje pacientove družine in okolice. Posamezniki, zasvojeni $z$ alkoholom so celo $v$ očeh strokovnjakov pogosto bolj krivci kot bolniki. Ko so zdravnike družinske medicine vprašali, zakaj svojih pacientov ne sprašujejo o pivskih navadah in jim v zvezi s tem ne ponudijo nasveta, so ti največkrat odgovorili, da za to potrebujejo več terapevtskih in še zlasti motivacijskih veščin. Med ovire pri uveljavljanju kratkih ukrepov zato lahko štejemo negativni odnos do teh ukrepov, pomanjkanje znanja, pa tudi vsakodnevno rutinsko delo na osnovni ravni (10, 12-19). Med dejavniki, ki bi bili potrebni za uveljavitev kratkih ukrepov, navajajo podporo vlade, prizadevanje vodstva in programe na delovnem mestu (1, 20-22).

\section{Kaj menijo pacienti o pogovorih o alkoholu?}

Nekateri zdravniki se bojijo, da bodo izgubili paciente, če bodo začeli pogovor o pitju alkohola. Anketa med pacienti po obisku v ambulanti na Finskem je pokazala,

${ }_{1}^{1}$ Profesor za medicino zasvojenosti, specialist splošne medicine, Psihiatrični oddelek, Univerzitetna bolnišnica Tampere, Medicinska fakulteta, Univerza v Tampere, FIN-33014 Univerza v Tampere, Finska

E-pošta: kaija-liisa.seppa @uta.fi 
da je imelo $1.8 \%$ pacientov, ki so jih vprašali o pitju alkohola (235/665), do teh vprašanj odklonilen odnos, 29.1 odstotkov pacientov je bilo nevtralnih, 20.2 odstotkov jih je imelo do vprašanj o pitju pozitiven odnos in 48.8 odstotkov zelo pozitiven odnos (23). Nacionalna anketa je pokazala, da je 90 odstotkov Fincev, starih 15 do 69 let, ki so v zadnjih 12 mesecih potrebovali zdravstvene storitve, na vprašanja o pitju alkohola gledali pozitivno (24).

Kot kažejo posnetki obiskov pri zdravniku in zdravstvena dokumentacija, pogovoru o alkoholu ne sledi vedno tudi nasvet, tudi takrat ne, ko bi ga pacient potreboval (25, 26). Takšne so tudi ugotovitve anket, ko je informacije dal pacient $(27,28)$. Po drugi strani pa je več kot dve tretjini vseh posameznikov, ki so nasvet dobili, menilo, da jim je koristil (24).

\section{Rezultati izvajanja}

Že več let poskušajo v osnovnem zdravstvenem varstvu po svetu uvesti uporabo kratkih ukrepov $(1,22,29)$. V ZDA predstavljajo kratki ukrepi prednostni preventivni ukrep pri tveganem in škodljivem uživanju alkohola. Ker pa ga večina tistih pacientov, ki bi ga potrebovali, ni deležna, pozivajo k večji zavzetosti pri uvajanju teh ukrepov (30). Kljub skromnim rezultatom in omejeni uporabi kratkih ukrepov, lahko sklepamo, da bolj intenzivni napori prinašajo boljše rezultate. (11).

V ZDA so v dveh populacijskih raziskavah ugotavljali, kako pogosto so $\mathrm{v}$ preteklih 12 mesecih paciente na primarni ravni povprašali o težavah v zvezi z uporabo alkohola in drog. Podatki pri 7.301 pacientih v osnovnem zdravstvenem varstvu so pokazali, da so takšna vprašanja zastavili 28.3 odstotkom pacientov; 43.3 odstotkom tistih s pozitivnimi izsledki tega presejanja pa so predlagali, naj zmanjšajo uporabo alkohola oz. drog (27). V raziskavi »Zdravstveno varstvo za skupnosti » iz I. 1998 sta bila ta dva deleža $29 \%$ in $48.6 \%$. O uporabi alkohola in drog so večkrat vprašali moške, mlade ljudi, tiste z višjo in visoko izobrazbo, z več boleznimi, z višjimi vrednostmi pri vprašalniku AUDIT, in tiste, ki so živeli v mestu (28). V Finski populacijski raziskavi so o pitju alkohola povprašali približno eno tretjino sodelujočih, in sicer predvsem mlade, moške, prekomerne pivce in tiste z višjim družbeno-ekonomskim statusom. Ena tretjina vprašanih je bila deležna nasveta, in sicer največkrat prekomerni pivci in tisti z normalnim indeksom telesne mase (24).

Enaka vprašanja so preučevali tudi v raziskavah, ki so temeljile na dejanskih obiskih pri zdravniku. V Finski študiji $(n=1203)$ je bilo med zdravniškim pregledom
11.6 odstotkov sodelujočih vprašanih o pitju alkohola, oziroma so dobili nasvet v zvezi s tem (23).

Lock in Kaner poročata, da dobi v Angliji 62 odstotkov tveganih pivcev nasvet medicinske sestre. Vrednost testa AUDIT je bil najpomembnejši napovedni dejavnik za kratek ukrep, temu je sledil moški spol. Dejavniki, kot so starost pacienta, družbeni razred ali lastnosti medicinske sestre, niso imeli vpliva na izvajanje ukrepov (21).

V ZDA so z ukrepi na državni ravni in s posredovanjem kliničnih opomnikov po elektronski poti povečali odstotek kratkih ukrepov med prekomernimi pivci v ambulantah za veterane s 5.5 na 29 odstotkov (31). Vsem zdravnikom splošne medicine na Finskem, ki delajo na primarni ravni, so poslali vprašalnike, da bi ugotovili, če je program kratkih ukrepov že postal del njihovega vsakodnevnega dela. Odgovorilo jih je 50.9 odstotka (1610/3163) in 78.5 odstotkov jih je izjavilo, da opravljajo kratke ukrepe. Redno jih uporablja kratke ukrepe 17.2 odstotka vprašanih in občasno 61.3 odstotki (32). Vse te raziskave kažejo, da je uporaba kratkih ukrepov oportunistična in še ni sistematična.

\section{Mnenje strokovnjakov o pogovoru o pitju alkohola}

V osnovnem zdravstvenem varstvu obstajata dva pogleda na uporabnost kratkih ukrepov. Po mnenju nekaterih bi se morala uporaba kratkih ukrepov čim bolj uveljaviti. To mnenje temelji na ugotovitvah raziskav o njihovi učinkovitosti. Spet drugi pa menijo, da kratki ukrepi, kljub svoji učinkovitosti, niso primerni za vsakdanje delo v osnovnem zdravstvenem varstvu. Tako mislijo predvsem zdravniki družinske medicine in na to kaže dejstvo, da se kratki ukrepi na primarni in specialistični ravni, kljub številnim poskusom, še niso uveljavili v večjem obsegu. Izračuni kažejo, da bi morali za eno izboljšanje, v presejanje zajeti okrog 300 pacientov, kar pomeni za zdravnike družinske medicine veliko izgubo časa in denarja (33). Po drugi strani pa nekatere raziskave kažejo, da so kratki ukrepi stroškovno učinkoviti in da nam prihranijo 4.5 krat več denarja, kot ga zanje potrošimo (34).

Težava znanstvenih študij o učinkovitosti je $v$ tem, da $v$ glavnem ne potekajo $v$ okviru rutinskega dela v zdravstvenem varstvu, in je dejavnost pozabljena kmalu po zaključku projekta. Dodatno delo, ki ga zahteva pisanje študijskih dnevnikov med natrpanim delavnikom, je med zdravniki družinske medicine naletelo na odpor. Menili so, da to ni naloga zanje in so si zato prizadevali, da bi k opravljanju kratkih ukrepov 
pritegniti medicinske sestre in druge zdravstvene delavce $(1,21)$.

Videti je, da se je odnos vodilnih do tega vprašanja spremenil. Mnenja so namreč, da je treba razširiti uporabo kratkih ukrepov v ustanovah osnovnega zdravstvenega varstva. Potekajo pa še razprave o tem, ali naj bo presejanje sistematično ali je boljši kak drug pristop. Izobraževanje zdravnikov družinske medicine na področju kratkih ukrepov, ki ga je spodbujalo vodstvo, ni bilo prav priljubljeno in mnogi zdravniki so imeli celo občutek, da jih obsojajo, ker ne opravljajo kratkih ukrepov.

\section{Kaj bi lahko storili?}

Trdni znanstveni dokazi govore v prid uporabe kratkih ukrepov, ki naj jih na osnovni ravni izvajajo zdravniki družinske medicine in medicinske sestre. Prav tako tudi pozitiven odnos pacientov do teh ukrepov govori za to, da je treba delo $v$ tej smeri nadaljevati. Zaradi nerazumevanja so mnogi zdravstveni delavci $v$ osnovnem zdravstvenem varstvu mnenja, da kratki ukrepi ne sodijo $v$ njihovo vsakodnevno delo. Ta napačna mnenja na eni in resnična dejstva na drugi strani so zbrana v Tabeli 1.

Tabela 1. Kratki ukrepi zaradi pitja alkohola na primarni ravni.

\begin{tabular}{|l|l|}
\hline Pomisleki & Dejstva \\
\hline Potrebne so terapevtske veščine & Dovolj so osnovne komunikacijske veščine \\
\hline Je zahtevna & Je nezahtevna \\
\hline Potreben je dodatni čas & Opravimo jo lanko med rednim delom \\
\hline Potrebno je več administrativnega dela & Normalen obseg administracije \\
\hline Potrebni so posebni vprašalniki & Zadostujejo kratka ustna vprašanja \\
\hline Žali paciente & Pomaga pacientom \\
\hline Moralna vprašljivost & Primerljiva je $z$ drugimi pogovori \\
\hline
\end{tabular}

Glavno oviro predstavlja napačno mnenje, da je kratek ukrep dodatna in zahtevna naloga. To je mnenje raziskovalcev. Seveda so pomembne izboljšave metode (35), vendar na osnovni ravni že preprosto dejstvo, »da o problemu spregovorimo «, lahko privede do dobrih rezultatov. Zdravstveni delavci v osnovnem zdravstvenem varstvu se bojijo uporabe posebnih metod, zato $s$ tem delom odlašajo ali se mu celo izognejo, češ da nimajo časa za takšne pogovore.

Druga ovira je uporaba strukturiranih vprašalnikov. Zdravniki družinske medicine imajo neposreden pogovor s pacientom raje kot pisne vprašalnike. Vendar pogovor o alkoholu lahko začnemo s preprostim vprašanjem: «Povejte mi prosim, koliko alkohola popijete? « Dobra možnost je tudi uporaba kratkega strukturiranega vprašalnika med pogovorom. Tu pride $v$ poštev kratek test AUDIT-C (36). Osnovna metoda tega preventivnega ukrepa je, da posameznika povprašamo, v kakšnem položaju je in kakšne informacije bi potreboval. Med spraševalcem in pacientom se zgradi odnos, ki je bolj partnerski kot didaktičen, temelji pa na osebnem in verbalnem stiku.

Eden od razlogov proti uporabi kratkih ukrepov je tudi ta, da zdravniki družinske medicine nimajo terapevtskih znanj, ki bi jih potrebovali, ko ugotovijo, da ima pacient dejansko težave $z$ alkoholom. V mnogih državah je na voljo veliko pisnih materialov, namenjenih tveganim pivcem. Najosnovnejši kratek ukrep je že to, da pacientu izročimo takšen letak in mu namenimo nekaj sočutnih besed. Če ja pacient zasvojen z alkoholom, ga še vedno lahko napotimo k specialistu za bolezni zasvojenosti. Danes v bližini gotovo najdemo strokovnjaka, ki obvlada več motivacijskih veščin. Kakorkoli, veliko slabše in bolj neetično je, če se na morebitno težavo sploh ne odzovemo, kot če o problemu spregovorimo, ne glede na to kako obvladamo motivacijske veščine. 
Da bi dosegli večje znanstveno utemeljene javnozdravstvene koristi kratkih ukrepov, morajo na vprašanje o pivskih navadah vsaj enkrat v življenju odgovoriti vsi pacienti. Prilagojeno (oportunistično) presejanje, najprej pri rizičnih primerih, npr. pri poškodovancih, ki mu nato sledi kratek ukrep, je morda najenostavnejši način, kako za začetek uvesti te ukrepe $v$ sistematično delo ustanove in kako pridobiti nekaj izkušenj na tem področju. Tudi na dolgi rok te oportunistični kratki ukrepi zajamejo le majhen delež primerov, zato se javnozdravstvene koristi teh ukrepov lahko izgubijo. Na osnovni ravni bi bila morda bolj smiselna kontinuirana obravnava posameznika, s katero bi pridobili osnovne podatke o življenjskem slogu vseh pacientov, ne pa presejanje vsakega pacienta ob vsakem obisku v ambulanti. Idealno bi bilo, da bi o uživanju alkohola ob primernem času povprašali vsakega novega pacienta, škodljive in tvegane pivce ob vsakem obisku in paciente $z$ nizkim tveganjem, ki kažejo simptome škodljivega pitja alkohola oz. ki že dolgo niso bili vprašani o pitju alkohola. Na ta način bi dobil zdravnik družinske medicine vpogled $v$ trenutne pivske navade vsakega pacienta. Tako bi potekalo sistematično presejanje, prilagojeno vsakodnevnemu delu v ustanovah osnovnega zdravstvenega varstva. V teh primerih lahko brez dodatnih naporov ali stroškov, potrebnih za organizacijo posebnega sistematičnega anketiranja, izkoristimo ugoden trenutek in dober odnos med pacientom in zdravnikom za presejanje in izvajanje kratkih ukrepov.

Za dosego tega cilja je koristno dodatno izobraževanje strokovnjakov s področja splošne oz. družinske medicine ter medicine dela (37). Vključitev širših preventivnih znanj v izobraževalne programe prispeva k oblikovanju zdravnikove strokovne identitete. Ni pa zagotovila, da program posebnega izobraževanja za kratke ukrepe v zvezi z alkoholom izboljša odnos do teh ukrepov pri tistih, ki so glede njih neodločni oziroma jih to delo ne zanima, koristijo le tistim z izoblikovano strokovno identiteto (38). Poleg tega pa je dejstvo, da lahko izvajanje takšnih kratkih ukrepov izboljša kakovost dela v osnovnem zdravstvenem varstvu (39), lahko še dodatna spodbuda za njihovo uveljavitev.

Strokovnjaki v osnovnem zdravstvenem varstvu, zdravniki družinske medicine in medicinske sestre so visoko strokovno usposobljeni za opravljanje kratkih ukrepov pri tveganem in škodljivem pitju alkohola. Vse, kar morajo storiti, je, da se soočijo s tem izzivom, pozabijo na moralne pomisleke in uporabijo znanje, ki ga imajo. Kratki ukrepi niso dolgotrajna obravnava, pri njih ni izgube časa, mnogim pacientom pa prinašajo zadovoljstvo in izboljšanje zdravja. Nekateri kolegi bi se morda radi še dodatno izobraževali v motivacijskih veščinah in prevzeli odgovornost za tiste posameznike, ki potrebujejo več kot le osnoven kratek ukrep.

$\mathrm{Na}$ voljo so vse sestavine za opravljanje kratkih ukrepov. Kot je napisal Tolstoj, se mora odločanje o tem ali ukrepati ali ne, začeti pri glavnih igralcih. $\mathrm{V}$ našem primeru so to zdravniki in medicinske sestre $v$ osnovnem zdravstvenem varstvu. Prevzemite vodstvo, pametno se odločite in prilagodite izvajanje presejanja in kratkih ukrepov svojim in pacientovim potrebam.

\section{Literatura}

1. Heather $\mathrm{N}$ (Ed.). WHO Collaborative Project on Identification and Management of Alcohol-Related Problems in Primary Health Care: report on phase IV: development of countrywide strategies for implementing early identification and brief intervention in primary health care. Geneva: World Health Organization, 2006.

2. Salaspuro M. Intervention against hazardous alcohol consumption - secondary prevention of alcohol problems. In: Berglund M, Thelander E, Jonsson E (Ed.) Treating alcohol and drug abuse. Weinheim: Wiley-VCH, 2003: 1-41.

3. Ballesteros J, Duffy JC, Querejeta I, Arino J, Gonzalez-Pinto A. Efficacy of brief interventions for hazardous drinkers in primary care: systematic review and meta-analyses. Alcohol Clin Exp Res 2004; 28: 608-18.

4. Kaner EFS, Beyer F, Dickinson HO, Pienaar E, Campbell F, Schlesinger C, Heather N, Saunders J, Burnand B. Effectiveness of brief alcohol interventions in primary care populations. Cochrane Database of Systematic Reviews 2007; 2: CDC004148.

5. West R, McNeill A, Raw M. Smoking cessation guidelines for health professionals: an update. Thorax 2000; 55: 987-99.

6. Silagy C, Stead LF. Physician advice for smoking cessation. Cochrane Database Syst Rev 2004; 4: CD000165.

7. Russell MA, Wilson C, Taylor C, Baker CD. Effect of general practitioners' advice against smoking. BMJ 1979; 2: 231-5.

8. Kreuter MW, Cheda SG, Bull FC. How does physician advice influence patient behaviour?: evidence for a priming effect. Arch Fam Med 2000; 9: 426-33.

9. West R, McEwen A, Bolling K, Owen L. Smoking cessation and smoking patterns in the general population: a 1-year follow-up. Addiction 2001; 96: 891-902.

10. Roche AM, Freeman T. Brief interventions: good in theory but weak in practice. Drug Alcohol Rev 2004; 23: 11-8.

11. Nilsen $P$, Aalto M, Bendtsen B, Seppä K. Effectiveness of strategies to implement brief alcohol intervention in primary health care - a systematic review. Scand J Primary Health Care 2006; 24: 5-15.

12. Aalto M, Pekuri P, Seppä K. Primary health care nurses' and physicians' attitudes, knowledge and beliefs regarding brief intervention for heavy drinkers. Addiction 2001; 96: 305-11.

13. Kääriäinen J, Sillanaukee $P$, Poutanen $P$, Seppä K. Opinions on alcohol-related issues among professionals in primary, occupational, and specialized health care. Alcohol Alcoholism 2001; 36: 141-6.

14. Johansson K, Bendtsen P, Åkerlind I. Early intervention for problem drinkers: readiness to participate among general practitioners and nurses in Swedish primary health care. Alcohol Alcoholism 2002; 37: 38-42. 
15. Aira M, Kauhanen J, Larivaara P, Rautio P. Factors influencing inquiry about patients' alcohol consumption by primary health care physicians: qualitative semi-structured interview study. Family Practice 2003; 20: 270-5.

16. McCormic KA, Cochran NE, Back AL, Merrill JO, Williams EC, Bradley KA. How primary care providers talk to patients about alcohol: a qualitative study. J Gen Intern Med 2006; 21: 966-72.

17. Saitz R, Friedmann PD, Sullivan LM, Winter MR, LloydTravaglini C, Moskowitz MA, Samet JH. Professional satisfaction experienced when caring for substance-abusing patients: faculty and resident physician perspectives. J Gen Intern Med 2002; 17: 373-7.

18. Kaner EFS, Heather N, McAvoy BR, Lock CA, Gilvarry E. Intervention for excessive alcohol consumption in primary health care: attitudes and practices of English general practitioners. Alcohol Alcohol 1999; 34: 559-66.

19. Poplas-Susič T, Kersnik J, Kolšek M. Why do general practitioners not screen and intervene regarding alcohol consumption in Slovenia?: a focus group study. Wien Klin Wochenschr 2010; 122 (Suppl 2): 68-73.

20. Kersnik J, Poplas-Susič T, Kolšek M, Švab I. What may stimulate general practitioners to undertake screening and brief intervention for excess alcohol consumption in Slovenia?: a focus group study. J Int Med Res 2009; 37: 1561-9.

21. Lock CA, Kaner EF. Implementation of brief alcohol interventions by nurses in primary care: do non-clinical factors influence practice? Family Practice 2004; $21: 270-5$.

22. Babor TF, Higgins-Biddle JB. Alcohol screening and brief intervention: dissemination strategies for medical practice and public health. Addiction 2000; 95: 677-86.

23. Aalto M, Seppä K. Usefulness, length and content of alcoholrelated discussions in primary health care: the exit-poll survey. Alcohol Alcoholism 2004; 39: 532-5

24. Mäkelä P, Havio M, Seppä K. Alcohol-related discussions in health care: a population view. Addiction [epub ahead of print]

25. Seppä K, Aalto M, Raevaara L, Peräkylä A. Brief intervention for risky drinking -analysis of videotaped consultations in primary health care. Drug Alcohol Review 2004; 23: 167-70.

26. Bradley KA, Williams EC, Achtmeyer CE, Volpp B, Collins BJ, Kivlahan DR. Implementation of evidence-based alcohol screening in the Veterans Health Administration. Am J Manag Care 2006; 12: 597-606.
27. Edlund MJ, Unützer J, Wells KB. Clinician screening and treatment of alcohol, drug, and mental problems in primary care. Medical Care 2004; 42: 1158-66.

28. D'Amico EJ, Paddock SM, Burnam A, Kung F-Y. Identification of and guidance for problem drinking by general medical providers. Medical Care 2005; 43: 229-36.

29. Seale JP, Monteiro MG. The dissemination of screening and brief intervention for alcohol problems in developing countries: lessons from Brazil and South Africa. Nordic Studies on Alcohol and Drugs 2009; 25: 565-77.

30. Williams EC, Achtmeyer CE, Kivlahan DR, Greenberg D, Merril JO, Wickitzer TM et al. Evaluation of an electrionic clinical reminder to facilitate brief alcohol-counseling interventions in primary care. J Stud Alcohol Drugs 2010; 71: 720-5.

31. Lapham GT, Achtmeyer CE, Williams ED, Hawkins EJ, Kivlahan DR, Bradley KA. Increased documented brief alcoho interventions with a performance measure and electronic decision support. Med Care [epub ahead of print].

32. Seppä K, Kuokkanen M. Implementing brief alcohol intervention in primary and occupational health care: reflections on two Finnish projects. Nordic Studies on Alcohol and Drugs 2009; 25: 505-14.

33. Beich A, Thorsen T, Rollnick S. Screening and brief intervention trials targeting excessive drinkers in general practice: systematic review and meta-analysis. Br Med J 2003; 327: 536-42.

34. Fleming MF, Mundt MP, French MT, Manwell LB, Stauffacher EA, Barry KL. Brief physician advice for problem drinkers: longterm efficacy and benefit-cost analysis. Alcohol Clin Exp Res 2002; 26: 36-43.

35. Heather $\mathrm{N}$. The case for extended brief interventions. Zdrav Var 2011; 50: 1-6.

36. Kriston L, Hölzel L, Weiser AK, Berner MM, Härter M. Metaanalysis: are 3 questions enough to detect unhealthy alcohol use? Ann Intern Med 2008; 149: 879-88.

37. Seppänen K, Aalto M, Seppä K. Influence of national brief intervention projects on brief intervention activity of Finnish primary care physicians. $7^{\text {th }}$ Conference of Inebria. Accessed March 21, 2011 from: www.inebria.net.

38. Anderson, P, Laurant, M, Kaner, E, Wensing, M, Grol, R. Engaging general practitioners in the management of hazardous and harmful alcohol consumption: results of a meta-analysis. $J$ Stud Alcohol 2004; 65: 191-9.

39. Saitz R, Horton NJ, Cheng DM, Samet JH. Alcohol counseling reflects higher quality of primary care. J Gen Intern Med 2008; 23: 1482-6. 